\title{
8. 日本聴覚医学会50周年記念シンポジウム「突発性難聴の50年」
}

平成17年 9 月 23 日 (金), (第50回日本聴覚医学会 総会学術講演会第二日目), 学会場である六本木ア カデミーヒルズ40において上記記念シンポジウムが 行われた。シンポシストは岩手医科大学名誉教授, 本学会顧問, 立木 孝 (司会兼), 京都洛東耳鼻咽 喉科院長, 本学会顧問, 志多 享, 東京大学名誉教 授, 本学会顧問, 野村恭也, 慶應大学名誉教授, 本 学会顧問, 神崎 仁の 4 人である。

また志多顧問は, 講演の中で, 鹿児島市の朝郎真 一郎会員に, 血管条に関する研究の一部の紹介を要 請し, 朝隈はこれに応じた。

はじめに司会の立木は，1944年 deKleyn によっ て最初に報告された本症が日本で研究の対象となっ た1955年から今年でちょうど50年が経過したこと， この50年の間に本症に関する研究が我が国でどのよ うに行われたかについてその概要を述べた。

神崎は「突発性難聴の回復性 (可逆性)について」 と題して, 主として本症の治癒, 不治癒が何によっ
て決まるのか，種々の観点から考察した結果を述べ た。難聴の程度，オージオグラムの型，治療開始の 早さ，などである。また治療によらない自然治癒の 率や可逆性のメカニスムの考光方についても述べ た。

野村は「突発性難聴の病理」と題して, 自験例と 文献例に見られる病態，とくに蓋膜の変化について 述べた。特にその変化がウイルスによる变化と類似 していることに注目し，自験例についてもあらため て再検討, 特に蓋膜の変化がウイルス感染を示唆す るものであることを述べ，聴力の回復をみない突発 性難聴はウイルス潜伏感染の再活性化によるものと の考えを示した。

志多は「突発性難聴の病変部位について一蝸牛電 気生理学的立場から一」と題して長い間の聴覚電気 生理学的実験の中から, 本症の本態に迫るいくつか の知見を述べた。特に, “突然起り, 治る”という 本症の病態を考える限り，その障害は $\mathrm{EP} て ゙ あ り ，$

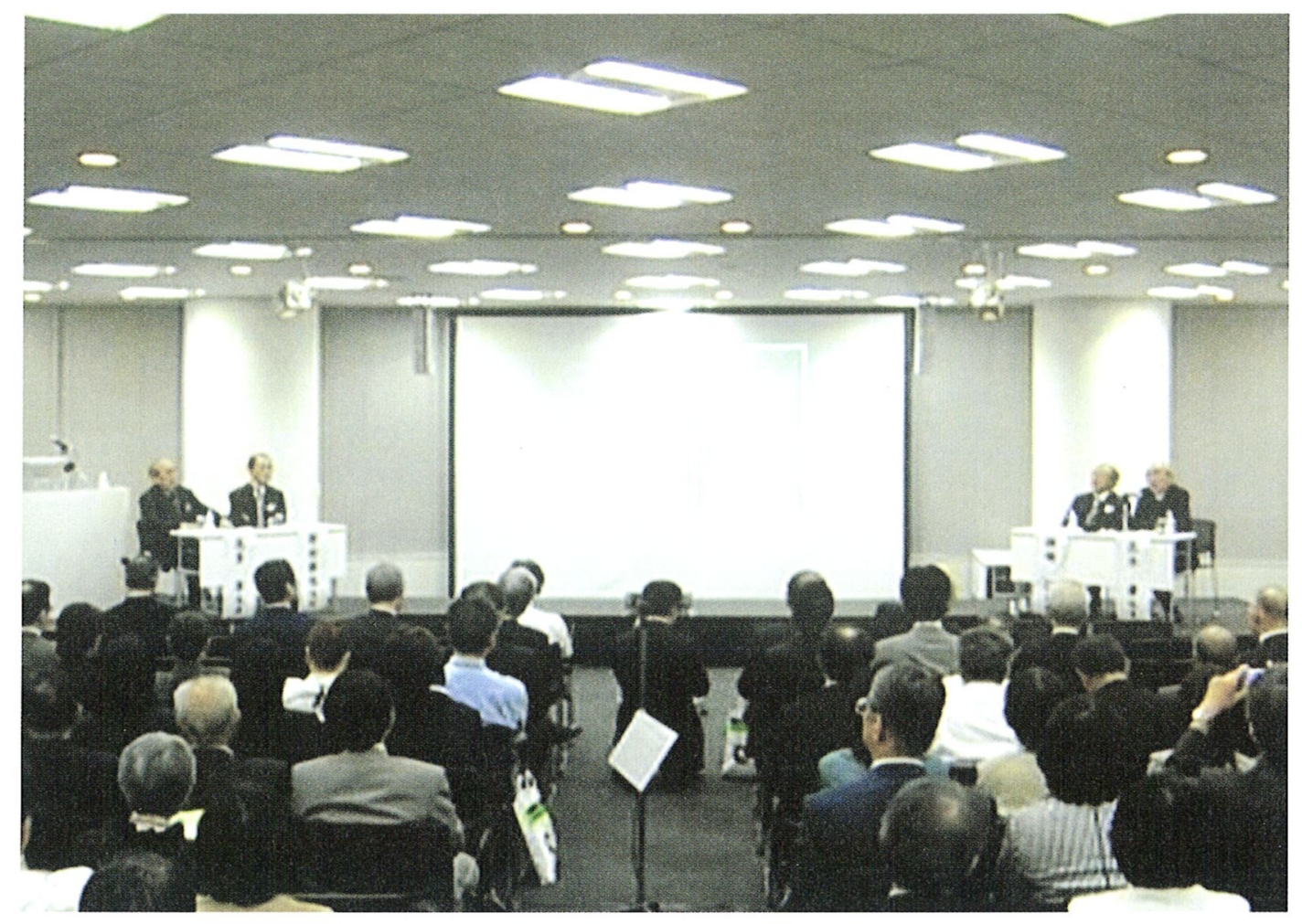


血管条であるとせざるを得ないと云う以前からの考 え方をあらためて強調した。また朝隈は演者の要請 によって，有毛細胞を障害しないで血管条を障害す る血行障害があるか, 全回転の EP が一気に障害さ れる血行障害があるか, についての自らの実験や推 理の結果について追加した。

最後に立木は「突発性難聴のオージオグラム」と 題して多数の治癒した例, 治癒はしないが改善した 例, 改善もしない例のそれぞれについて，そのオー ジオグラムの特徴を呈示し, 血管条障害で改善する ことを原則とするループ利尿剤中毒のオージオグラ 么変化と比較しながら, 突発性難聴の病変が毛細胞
障害と血管条障害との組み合わせであるという考え をのべた。

その後, 若干の意見交換が行われ, 最後に, 司会 者でもある立木は，「本学会の歴史と共に我が国の 突発性難聴の研究は50年の歴史を終えた。われわれ 4 人にとってこの 50 年は決して長い年月ではなかっ た。今研究をはじめたばかりの若い諸君が，50年た った時に何を思い何を考えるだろうか。時は待って くれない。一層の精進を期待してこのシンポジウム を閉じたい。」と述べて閉会した。

(立木 孝)

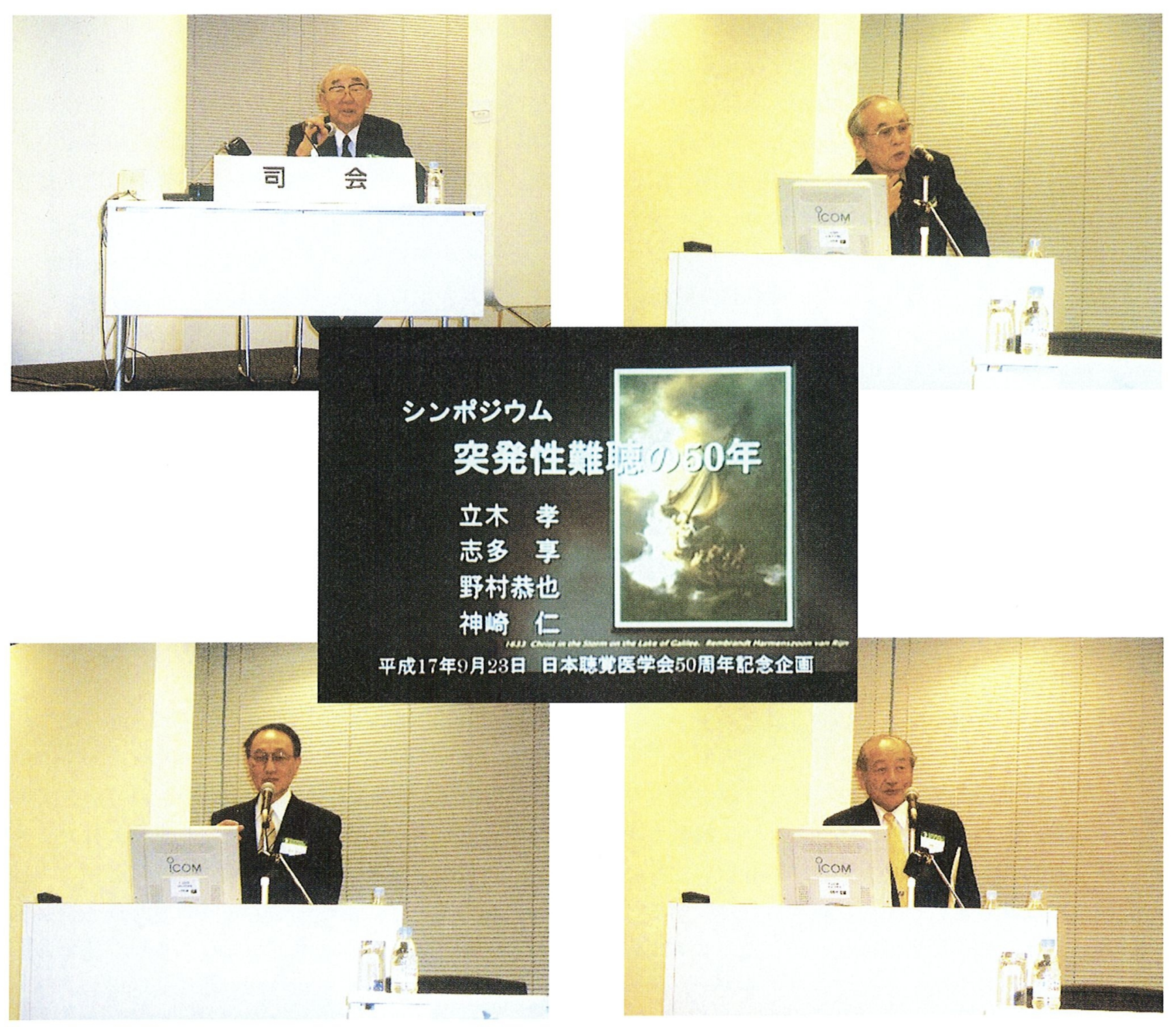

